\title{
NAT2 wt Allele
}

National Cancer Institute

\section{Source}

National Cancer Institute. NAT2 wt Allele. NCI Thesaurus. Code C51048.

Human NAT 2 wild-type allele is located in the vicinity of $8 p 22$ and is approximately $10 \mathrm{~kb}$ in length. This allele, which encodes arylamine $\mathrm{N}$-acetyltransferase 2 protein, is involved in the activation/deactivation of arylamine and hydrazine compounds. Certain allelic variants of the NAT 2 gene are associated with systemic lupus erythematosus and certain types of cancer such as bladder cancer and colorectal cancer. 